\title{
Karyotype and COI sequences of Chironomus sokolovae Istomina, Kiknadze et Siirin, 1999 (Diptera,Chironomidae) from the bay of Orkhon River, Mongolia
}

\author{
Viktor V. Bolshakov', Alexander A. Prokin ${ }^{1,2}$ \\ I Papanin Institute for Biology of Inland Waters Russian Academy of Sciences, Yaroslavl reg., Nekouz prov., Borok, \\ 152742, Russia 2 Cherepovets State University, Lunacharski 5, Cherepovets, 162600, Vologda Oblast', Russia \\ Corresponding author: Viktor V. Bolshakov (victorb@ibiw.ru) \\ Academic editor: I. Sharakhov | Received 26 March 2021 | Accepted 10 May 2021 | Published 27 May 2021 \\ http://zoobank.org/71A8C35F-919A-4D1B-8C6A-F17940C67DF3 \\ Citation: Bolshakov VV, Prokin AA (2021) Karyotype and COI sequences of Chironomus sokolovae Istomina, \\ Kiknadze et Siirin, 1999 (Diptera, Chironomidae) from the bay of Orkhon River, Mongolia. CompCytogen 15(2): \\ 149-157. https://doi.org/10.3897/compcytogen.v15.i2.66549
}

\begin{abstract}
Chironomus sokolovae Istomina, Kiknadze et Siirin, 1999 (Diptera, Chironomidae) is recorded from Mongolia for the first time. Eleven banding sequences determined in the Mongolian population were previously known from Altai and Yenisei populations: sokA1, sokB1, sokB2, sokC1, sokC2, sokD1, sokD2, sokE1, sokF1, sokF2 and sokG1. The additional B-chromosomes are absent. DNA-barcoding of COI gene was carried out for this species for the first time. The phylogenetic tree estimated by Bayesian inference showed a high similarity of the studied species with Ch. acutiventris Wülker, Ryser et Scholl, 1983 from the Chironomus obtusidens-group. The estimated genetic distance K2P between Ch. sokolovae and Ch. acutiventris is much lower $(0.38 \%)$ than the commonly accepted threshold of $3 \%$ for species of genus Chironomus Meigen, 1803. Our results show that the accepted cytogenetic criteria of species level in the genus Chironomus are more in accordance with morphological ones of the same level, than with molecular-genetic criteria accepted for species COI genetic distance.
\end{abstract}

\section{Keywords}

Chironomidae, Chironomus sokolovae, COI, Diptera, DNA-barcode, karyotype, Mongolia

Copyright ViktorV. Bolshakov,Alexander A. Prokin. This is an open access article distributed under the terms of the Creative Commons Attribution License (CC BY 4.0), which permits unrestricted use, distribution, and reproduction in any medium, provided the original author and source are credited. 


\section{Introduction}

At present time, nine species of Chironomus Meigen, 1803 identified by imago (Hayford 2005; Shcherbina and Zelentsov 2008) are recorded from Mongolia. Seven additional species identified by imago were described from the country as new for science (Sasa and Suzuki 1997) but never found after the original description. Macrozoobenthos of the Orkhon (Kharkhorin) Reservoir on the Orkhon River near Kharkhorin city and river sections upstream and downstream of the reservoir, were studied for the first time during the fieldwork of the Joint Russian-Mongolian Complex Biological Expedition in 2017. Further research has shown that the species Chironomus sokolovae Istomina et al. 1999 was erroneously recorded by larvae as Ch. obtusidens Goethebuer, 1937 (Prokin and Sazhnev 2019) from the reservoir and connected sections of the Orkhon River with a total number of specimens up to $5000 \mathrm{ind} / \mathrm{m} 2$ and the total biomass up to $3,75 \mathrm{~g} / \mathrm{m} 2$. Larvae of Ch. commutatus Keyl, 1960 co-occurred with Ch. sokolovae (Prokin and Sazhnev 2019).

The species Ch. sokolovae belongs to Chironomus obtusidens-group including six species: Ch. acutiventris Wülker, Ryser et Scholl, 1983; Chironomus bavaricus Wülker, Ryser et Scholl, 1983; Ch. obtusidens Goethebuer, 1937; Ch. arcustylus Siirin, 2002; Ch. heterodentatus Konstantinov, 1956; Ch. sokolovae Istomina, Kiknadze et Siirin, 1999 (Siirin et al. 2002; Kiknadze et al. 2016). Chromosomal polymorphism and cytogenetic differentiation in this group are still poorly studied (Siirin et al. 2002; Kiknadze et al. 2007).

The known range of the species includes the Altai Krai, Altai Republic, and the Tyva Republic in Russia (Istomina et al. 2000; Siirin et al. 2002), and Mongolia (this publication). The species was described from the Chemal River (Altai Republic) and recorded from different water bodies in the Altai region and the Tyva Republic, where it co-occurred with Ch. acutiventris and Ch. heterodentatus (Istomina et al. 2000; Siirin et al. 2002). Numerous populations of Ch. sokolovae larvae inhabit silty sand of the Enisey River ripal zone, near the confluence of the Bolshoy and the Maliy Enisey Rivers (environs of Kyzyl city) (Siirin et al. 2002).

The karyotype and DNA barcoding of COI gene of the Ch. sokolovae from the Orkhon River (Mongolia) are described in this publication with the aim of clarifying the species position within the Ch. obtusidens-group.

\section{Materials and methods}

Two larvae were collected from the bay of the Orkhon River upstream of the reservoir: $47^{\circ} 10.734^{\prime} \mathrm{N}, 102^{\circ} 47.384^{\prime} \mathrm{E}$, in September 2017 . Depth $0.5 \mathrm{~m}$, bottom - silty sand. Temperature $20.0^{\circ} \mathrm{C}, \mathrm{pH} 7.2$, EC $172 \mathrm{mkSm} / \mathrm{sm}$, TDS $=98 \mathrm{mg} / \mathrm{l}$. For all analyses larvae were fixed in ethanol (95\%). Two fourth instar larvae were used for karyotype analysis by the ethanol-orcein technique (Dyomin 1989). A Micromed-6C (LOMO, 
St. Petersburg) light microscope equipped with standart (kit) oil objective $\times 100$, and camera ToupCam5.1 (China) were used for microscopy analysis. Cytomaps from Kiknadze et al. (2016), Keyl (1962), Wülker et al. (1983) and Dévai et al. (1989) were used to identify chromosome banding.

One larva which was studied karyologically was taken for the total DNA extraction using «M-sorb-OOM» (Sintol, Moscow) kit with magnet particles according to manufacturer's protocol. For amplification of COI (cytochrome oxidase subunit I) we used primers LCO1490 (5'-GGTCAACAAATCATAAAGATATTGG-3') and HCO2198 (5'-TAAACTTCAGGGTGACCAAAAAATCA -3') (Evrogen, Moscow) (Folmer et al. 1994). Amplification reaction was carried out in $25 \mu$ Lreaction mixture $(1 \times$ buffer, $1.5 \mu \mathrm{M} \mathrm{MgCl} 2,0.5 \mathrm{mM}$ of each primer, $0.2 \mu \mathrm{M}$ dNTP of each nucleotide, $17.55 \mu \mathrm{L}$ deionized water, $1 \mu \mathrm{L}$ template DNA, 1 unit Taq-polymerase (Evrogen, Moscow). PCR performed at $94^{\circ} \mathrm{C}(3 \mathrm{~min})$, followed by 30 cycles at $94^{\circ} \mathrm{C}(15 \mathrm{~s}), 50^{\circ} \mathrm{C}(45 \mathrm{~s})$, $72{ }^{\circ} \mathrm{C}(60 \mathrm{~s})$ and a final extention at $72{ }^{\circ} \mathrm{C}(8 \mathrm{~min})$. PCR products were visualized on $1 \%$ agarose gels and later purified by ethanol and ammonium acetate $(3 \mathrm{M})$. Both strands were sequenced on an Applied Biosystems 3500 DNA sequencer (Thermo Scientific, USA) following the manufacturer's instructions.

For alignment of COI nucleotide sequences we used MUSCLE in the MEGA6 software (Tamura et al. 2013). The MEGA6 was used to calculate pairwise genetic distances Kimura 2-parameter $(\mathrm{K} 2 \mathrm{P})$ with codon position preferences: $1^{\text {st }}, 2^{\text {nd }}, 3^{\text {rd }}$ and noncoding sites (Kimura 1980). The Bayesian analysis was performed using the program MrBayes v.3.2.6 (Ronquist and Huelsenbeck 2003; Ronquist et al. 2012) with settings suggested by Karmokov (2019), for 1,000,000 iterations and 1000 iterations of burn-in, nst = $6(\mathrm{GTP}+\mathrm{I}+\mathrm{G})$. The phylogenetic trees resulting in Bayesian inference analyses were visualized and edited using FigTree v.1.4.3 (http://tree.bio.ed.ac.uk/software/figtree/).

In addition, the 27 COI sequences of the genus Chironomus from "GenBank" and "Barcode of Life Data Systems" (BOLD; http://www.boldsystems.org) were analyzed. Accession numbers of used sequences in GenBank and BOLD: Chironomus acutiventris Wülker, Ryser et Scholl 1983 (AF192200.1), Ch. annularius Meigen, 1818 (AF192189.1), Ch. aprilinus Meigen, 1830 (KC250746.1), Ch. balatonicus Devai, Wulker et Scholl, 1983 (JN016826.1), Ch. bernensis Wülker \& Klötzli, 1973 (AF192188.1), Ch. borokensis Kerkis, Filippova, Schobanov, Gunderina et Kiknadze, 1988 (AB740261), Ch. cingulatus Meigen, 1830 (AF192191.1), Ch. commutatus Keyl, 1960 (AF192187.1), Ch. curabilis Belyanina, Sigareva et Loginova, 1990 (JN016810.1), Ch. dilutus Shobanov, Kiknadze et Butler, 1999 (KF278335.1), Ch. entis Shobanov, 1989 (KM571024.1), Ch. heterodentatus Konstantinov, 1956 (AF192199.1), Ch. heteropilicornis Wülker, 1996 (MK795772.1), Ch. luridus Strenzke, 1959 (AF192203.1), Ch. maturus Johannsen, 1908 (DQ648204.1), Ch. melanescens Keyl, 1961 (MG145351.1), Ch. nipponensis Tokunaga, 1940 (LC096172.1), Ch. novosibiricus Kiknadze, Siirin \& Kerkis, 1993 (AF192197.1), Ch. nuditarsis Keyl, 1961 (KY225345.1), Ch. obtusidens Goetghebuer, 1921 (CHMNO207-15*); Ch. piger Strenzke, 1959 (AF192202.1), Ch. pilicornis Fabricius, 1787 (BSCHI736-17*), Ch. plumosus (Linnaeus, 1758) (KF278217.1), 
Ch. riparius Meigen, 1804 (KR756187.1), Ch. tentans Fabricius, 1805 (AF110157.1), Ch. tuvanicus Kiknadze, Siirin et Wülker, 1993 (AF192196.1), Ch. whitseli Sublette \& Sublette, 1974 (KR683438.1). The COI sequence of Ptychoptera minuta Tonnoir, 1919 (KF297888) was used as outgroup in phylogenetic analysis.

\section{Results and discussions}

\section{Karyotype of Ch. sokolovae from the Orkhon River, Mongolia}

The chromosome set of the species is $2 \mathrm{n}=8$. The cromosome arm combination is $\mathrm{AB}$, $\mathrm{CD}, \mathrm{EF}$ and $\mathrm{G}$ (the Chironomus "thummi" cytocomlex). The additional B-chromosomes are absent. The chromosomes $\mathrm{AB}$ and $\mathrm{CD}$ are metacentric, $\mathrm{EF}$ is submetacentric, and $\mathrm{G}$ is telocentric. The karyotype of Ch. sokolovae is similar to Ch. acutiventris, but differs by fixed inversions in arms B, C, D and F (Kiknadze et al. 2016).

We found two different karyotypes (genotypic combinations) in both larvae from Mongolia: sokA1.1.B1.1.C1.2.D1.1.E1.1.F1.1.G1.1 and sokA1.1.B1.2.C1.2.D1.2.E 1.1.F1.2.G1.1., which consist of 11 banding sequences out of 18 known for the karyofund of this species (Istomina et al. 1999; Siirin et al. 2002) (Fig. 1).

Arm A. One banding sequence sokA1 1a-e 9a-e 2d-3e 15e-a 3f-i 12c-10a 4a-8g 14i13a 16a-c 2c-1f 16d-19f C.

Arm B. Two banding sequences: sokB2 was found in homozygous and heterozygous state with sokB1. Both banding sequences are still not mapped.

Arm C. Two banding sequences: sokC1 1a-4g 15e-14c 16e-17a 6hg 11d-12a 11c$8 \mathrm{a} 4 \mathrm{~h}-6 \mathrm{~b} 12 \mathrm{~b}-14 \mathrm{~b} 16 \mathrm{~d}-\mathrm{a} 7 \mathrm{~d}-\mathrm{a}$ 6f-c $17 \mathrm{~b}-22 \mathrm{~g} \mathrm{C}$, found in heterozygous state with sokC2 1a-4g 15e-c 11c-8a 4h-6b 12b-13f 12a-11d 6gh 17a-16e 14c-15b 14ab $16 \mathrm{~d}-\mathrm{a} 7 \mathrm{~d}-\mathrm{a}$ 6f-c 17b-22g C.

Arm D. Two banding sequences: sokD1 1a-2e 23b-21e 8d-10e 4a-8c 21d-16a 13d$15 \mathrm{e} 13 \mathrm{c}-11 \mathrm{a} 3 \mathrm{~g}-2 \mathrm{f} 23 \mathrm{c}-24 \mathrm{~g} \mathrm{C}$ found in homozygous and heterozygous state with sokD2 1a-3g 11a-13c 15e-13d 16a-21d 8c-4a 10e-8d 21e-24g C.

Arm E. One banding sequence sokE1 1a-2b 10b-5a 3e-2c 4h-3f 10c-13g C.

Arm F. Two banding sequences: sokF1 1a-i 19b-18a 2a-9f 13dc 11a-13b 10d-a 17d$14 \mathrm{a} 19 \mathrm{c}-23 \mathrm{f} \mathrm{C}$ found in homozygous and heterozygous state with sokF2 1a-i 19b18a 2a-6e 14a-17d 10a-d 13b-11a 13cd 9f-7a 19c-23f C.

Arm G. One banding sequence sokG1 was found. Not mapped.

All 11 banding sequences found in Mongolian larvae were previously known for both the Enisey and the Altai populations of studied species (Istomina et al. 1999; Siirin et al. 2002). In Mongolian and Enisey populations sokB1 banding sequence was found only in the heterozygous state, whereas in the Altai population it was in the homozygous state (Istomina et al. 1999; Siirin et al. 2002). 


\section{DNA-barcoding and phylogenetic analysis}

Single nucleotide sequence of Ch. sokolovae for the F6.2 gene from the tissue-specific Balbiani rings locus (Alieva et al. 2004) is accessible in GenBank (AF521040), while there is no sequences for barcoding. We obtained the COI barcode for Ch. sokolovae with the length of 665 nucleotides (percentage A: 16.9; T: 25.3; G: 11.8; C: 12.5) and deposited it into the GenBank database with accession number - MW471100.

Pairwise genetic distances between Ch. sokolovae and the members of the Ch. obtusidens group obtained by K2P model (Kimura 1980) shown high variability. Calculated distance between sequences of $C h$. sokolovae and $C h$. acutiventris sequences was $0.38 \%$, Ch. heterodentatus $-4.60 \%$, Ch. obtusidens $-11.56 \%$.

According to Polukonova et al. (2009) and Proulx et al. (2013) Chironomus COI interspecific sequence divergences is about $3 \%$. In our study, interspecific divergence between Ch. sokolovae and Ch. acutiventris is $0.38 \%$, that is much lower than the 3\% accepted interspecific threshold. In most cases such low values of distances between species occur due to incorrect species identification when only morphological traits were used. To exclude a possibility of such mistake, we used karyological analysis and confirmed the accuracy of our species identification (Fig. 1).

Phylogenetic analysis using COI sequences showed groups of related species (Fig. 2), which concur with how these species were combined into the groups earlier on the basis of karyological and morphological traits (Kiknadze et al. 2016; Karmokov 2019). Obtained data are highly accurate $(-100 \%)$ and show that Ch. sokolovae belongs to the Chironomus obtusidens group and is closest to Ch. acutiventris.

\section{Conclusions}

The Species Ch. sokolovae and Ch. acutiventris are similar in their karyotypes but differ in a few fixed inversions in arms B, C, D and F (Kiknadze et al. 2016). The COI sequences of these species are also similar, which could be the effect of a close relationship between the species, indicative of their recent origin (Michailova et al. 2021), or could be the result of interspecific hybridization with fixation of mtDNA in one of the parental species in the population (Guryev and Blinov 2002; Polukonova and Dyomin 2010, 2013). Study by Siirin et al. (2002) mentioned the existence of interspecific hybrids of Ch. sokolovae and Ch. heterodentatus, which means that hybridization between the $C h$. sokolovae and Ch. acutiventris still occur as a result of living together in the same habitats and co-swarming. At the same time, the mtDNA sequences mostly allows the delimitation between sibling species in such groups of species as Ch. obtusidens, Ch. lacunarius, Ch. plumosus etc. (Fig. 2), that was originally founded based on morphological and cytogenetics traits. For a more detailed analysis of the species position within the group is needed to perform sequencing of mitochondrial and nuclear genomes, coupled with the preliminary cytogenetic and morphological analysis as obligatory. 

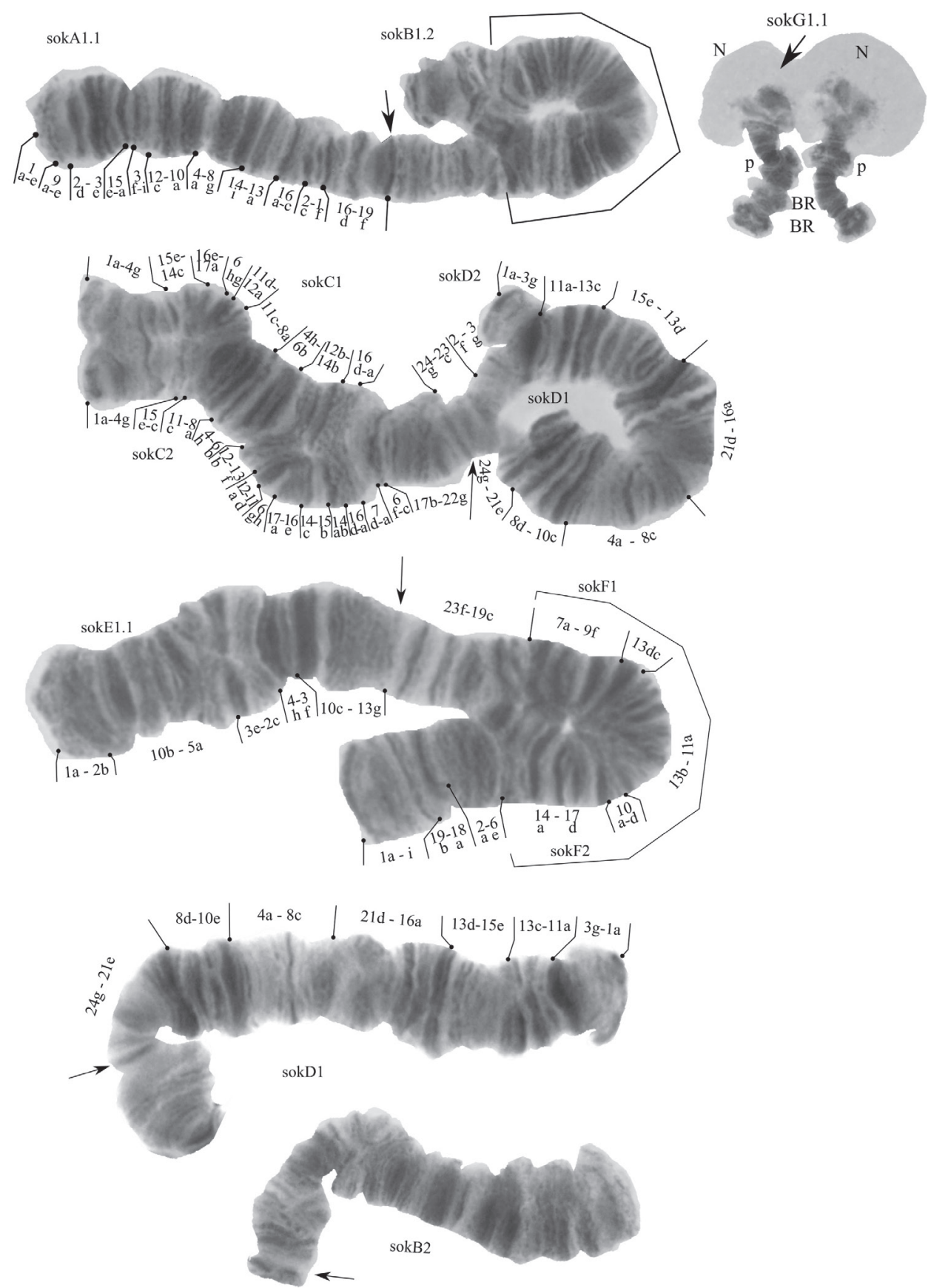

Figure I. Banding sequences of Ch. sokolovae from the Orkhon River, Mongolia. Arrows indicate centromeric band, sokA1, sokB1 and etc. - genotypic combinations of banding sequences in chromosome arms, $\mathrm{Br}$ - Balbiani rings, $\mathrm{N}$ - nucleous, $\mathrm{p}$ - puffs. sokA1.1. - mapped according to picture 2.51.2 by Kiknadze et al. (2016). 


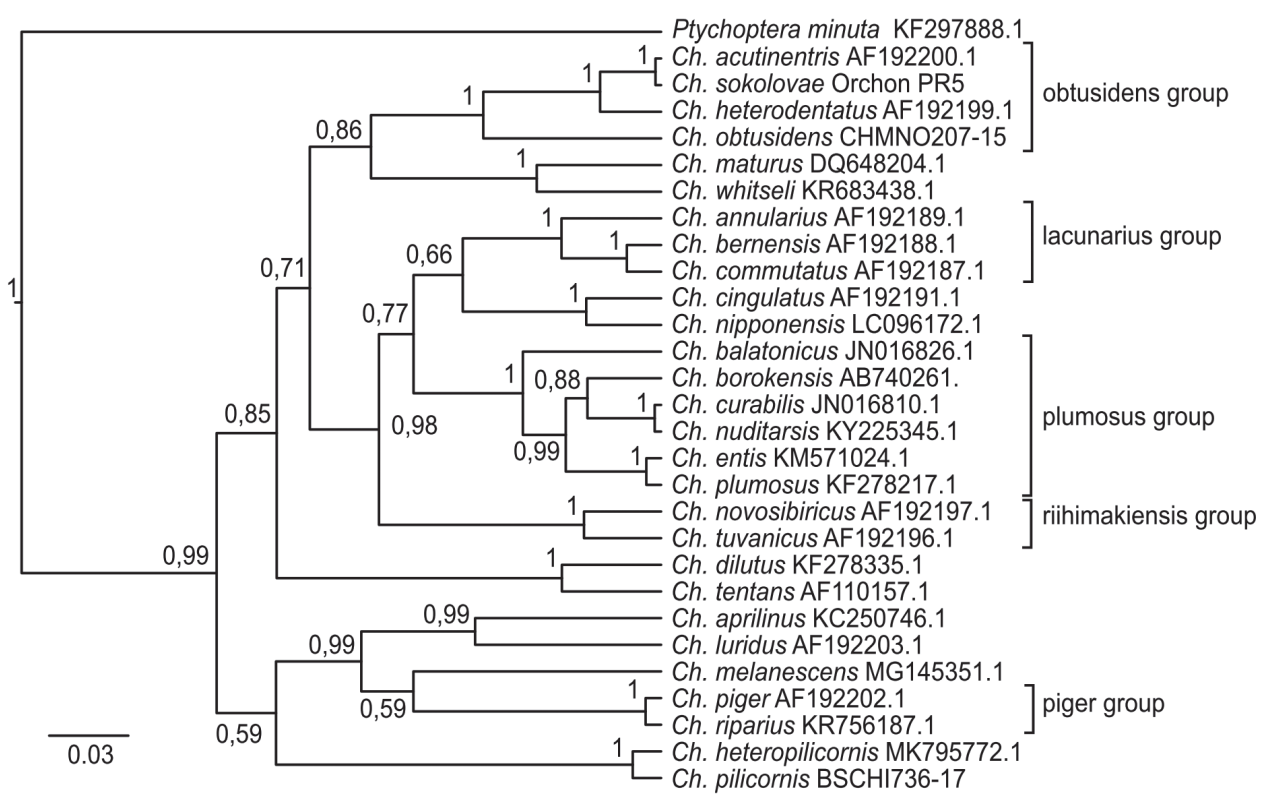

Figure 2. Bayesian tree of the analyzed samples of Chironomus spp. inferred from COI sequences. Species name, GenBank accession numbers and group name are shown to the right of the branches. Support values are given if they exceed 0.5 . The numbers at the nodes indicate posterior probabilities.

\section{Acknowledgements}

Material was sampled during the expedition of the hydrobiological team of the "Joint Russian-Mongolian Complex Biological Expedition of the Russian and Mongolian Academies of Sciences". The work was realized according to the Russia state projects AAAA-A19-119102890013-3, AAAA-A18-118012690106-7, 121050500046-8 and 121051100109-1. The authors are grateful to A.S. Sazhnev and A.V. Krylov (IBIW RAS) for help in fieldwork and to E.A. Movergoz, A.A. Bobrov, B.A. Levin (IBIW RAS) and M.Kh. Karmokov (IEMT RAS) for their help and consultations during all stages of the investigation and manuscript preparation; D.D. Pavlov (IBIW RAS) for the linguistic corrections of the text. The authors thank the reviewers for their valuable suggestions.

\section{References}

Alieva EV, Mayorov VI, Elisapenko EV, Adkison L, Blinov AG (2004) The structure and expression of the F6.2 gene from Chironomus thummi and other Chironomus species. Russian Journal of Genetics 40(3): 255-262. https://doi.org/10.1023/B:RUGE.0000021624.70775.b5

Dyomin SYu (1989) Variability of the degree of condensation of polytene chromosomes in the cells of different organs of Chironomus plumosus larvae from nature. PhD Thesis, Institute of Cytology of the USSR Academy of Sciences, Leningrad, 25 pp. [In Russian] 
Dévai Gy, Miskolczi M, Wülker W (1989) Standardization of chromosome arms B, C and D in Chironomus (Diptera, Chironomidae). Acta Biologica Debricina. Supplementum Oecologica Hungarica 2(1): 79-92.

Folmer O, Black M, Hoeh W, Lutz R, Vrijenhoek R (1994) DNA primers for amplification of mitochondrial cytochrome c oxidase subunit I from diverse metazoan invertebrates. Molecular Marine Biology and Biotechnology 3: 294-299.

Guryev VP, Blinov AG (2002) Phylogenetic relationships among holarctic populations of Chironomus entis and Chironomus plumosus in view of possible horisontal transfer of mitochondrial genes. Russian Journal of Genetics 38(3): 239-243. https://doi. org/10.1023/A:1014842415628

Hayford B (2005) New records of Chironomidae (Insecta: Diptera) from Mongolia with review of distribution and biogeography of Mongolian Chironomidae. Journal of the Kansas Entomological Society 78(2): 192-200. https://doi.org/10.2317/0406.24.1

Istomina AG, Kiknadze II, Siirin MT (1999) Karyological analysis of Chironomus gr. obtusidens species from the Altai. Tsitologiya 41(12): 1022-1031. [In Russian]

Istomina AG, Siirin MT, Polukonova NW, Kiknadze II (2000) Chironomus sokolovae sp. n. is a new species of the group obtusidens (diptera, chironomidae). Zoologichesky Zhurnal 79(8): 928-938. [In Russian]

Karmokov MK (2019) Karyotype characteristics, chromosomal polymorphism and gene COI sequences of Chironomus heteropilicornis Wülker, 1996 (Diptera, Chironomidae) from the South Caucasus. Comparative Cytogenetics 13(4): 339-357. https://doi.org/10.3897/ CompCytogen.v13i4.35572

Keyl H-G (1962) Chromosomenevolution bei Chironomus. II. Chromosomenumbauten und phylogenetische Beziehungen der Arten. Chromosoma 13(4): 464-514. https://doi. org/10.1007/BF00327342

Kiknadze II, Istomina AG, Gunderina LI (2007) Cytogenetic differentiation of natural populations of Chironomus obtusidens (Diptera, Chironomidae). Entomological Review 87(6): 658-669. https://doi.org/10.1134/S0013873807060036

Kiknadze II, Istomina AV, Golygina VV, Gunderina LI (2016) Karyotypes of Palearctic and Holarctic species of the genus Chironomus [Electronic resource]. Russian Academy of Sciences, Siberian Branch, Federal Research Center Institute of Cytology and Genetics. Novosibirsk, $489 \mathrm{pp}$.

Kimura MA (1980) Simple method for estimating evolutionary rate of base substitutions through comparative studies of nucleotide sequences. Journal of Molecular Evolution 16: 111-120. https://doi.org/10.1007/BF01731581

Michailova P, Lencioni V, Nenov M, Nikolov S (2021) Can DNA barcoding be used to identify closely related Clunio Haliday, 1855 species (Diptera: Chironomidae, Orthocladiinae)? Zootaxa 4927(1): 001-008. https://doi.org/10.11646/zootaxa.4927.1.1

Polukonova NV, Djomin AG, Mugue NS (2013) Molecular criteria in insects systematics: barcoding gene COI range of variability as a taxonomic criterion for genus, tribe, and subfamily, with Chironominae and Orthocladiinae midges (chironomidae, diptera) as a case study. Zhurnal Obshchei Biologii 74(1): 66-76. [In Russian]. 
Polukonova NW, Dyomin AG (2010) The results of complex analysis species of Chironomus group obtusidens (diptera, chironomidae) based on morphology, karyotype and molecular-genetic data. Entomologicheskie i paraziticheskie issledovaniya v Povolzhe 8: 8-13. [In Russian]

Polukonova NV, Djomin AG, Mugue NS, Shaikevich AE (2009) Comparison of Chironomus usenicus and Chironomus curabilis with species of the group plumosus (Diptera) inferred from the mitochondrial DNA Gene COI and by the polytene chromosomes banding pattern. Russian Journal of Genetics 45: 899-905. https://doi.org/10.1134/ S102279540908002X

Prokin AA, Sazhnev AS (2019) First data on macrozoobenthos of the Orkhon and Ider Reservoirs (Mongolia). Transactions of IBIW 85(88): 69-76.

Ronquist F, Teslenko M, van der Mark P, Ayres DL, Darling A, Hohna S, Larget B, Liu L, Suchard MA, Huelsenbeck JP (2012) MrBayes 3.2: efficient Bayesian phylogenetic inference and model choice across a large model space. Systematic Biology 61: 539-542. https://doi.org/10.1093/sysbio/sys029

Ronquist F, Huelsenbeck JP (2003) MRBAYES 3: Bayesian phylogenetic inference under mixed models. Bioinformatics 19: 1572-1574. https://doi.org/10.1093/bioinformatics/btg180

Sasa M, Suzuki H (1997) Studies on the Chironomidae (Diptera, Insecta) collected in Mongolia. Japanese Journal of Tropical Medicine and Hygiene 25(4): 149-189. https://doi. org/10.2149/tmh1973.25.149

Shcherbina GKh, Zelentsov NI (2008) Chironomids (diptera, chironomidae) fauna of some Mongolian waterbodies and watercourses. Inland Water Biology 1: 21-26. https://doi. org/10.1007/s12212-008-1004-3

Siirin MT, Kiknadze II, Istomina AG (2002) Cytogenetic differentiation of populations in Chironomus heterodentatus and Ch. sokolovae species of obtusidens group (diptera, chironomidae). Zoologichesky Zhurnal 81(12): 1476-1486. [In Russian]

Tamura K, Stecher G, Peterson D, Filipski A, Kumar S (2013) MEGA6: Molecular Evolutionary Genetics Analysis version 6.0. Molecular Biology and Evolution 30: 2725-2729. https://doi.org/10.1093/molbev/mst197

Wülker W, Ryser HM, Scholl A (1983) Revision der Gattung Chironomus Meigen (Diptera). VIII. Arten mit Larven des fluvatilis-typs (obtusidens-gruppe): C. acutiventris n. sp. und C. obtusidens Goth. Revue Suisse de Zoologie 90: 725-745. https://doi.org/10.5962/bhl. part. 82010 